\title{
Assessment of Soil loss Tolerance limit to Latosol, Argisol and Cambisolin the southern Minas Gerais state
}

\author{
Guilherme Henrique Expedito Lense ${ }^{1}$, Rodrigo Santos Moreira ${ }^{2}$, Taya Cristo Parreiras ${ }^{3}$, Luis Felipe Pigatto \\ Miranda Silva ${ }^{4}$, Alexandre Elias de Miranda Teodoro ${ }^{5}$, Derielsen Brandão Santana ${ }^{6}$, Talyson Melo Bolelli ${ }^{7}$, \\ Ronaldo Luiz Mincato ${ }^{8 *}$
}

\begin{abstract}
Soil Loss Tolerance $(\mathrm{T})$ reflects the maximum erosion rate that still allows a sustainable level of crop production. The $\mathrm{T}$ limit can be used to support the conservationist land-use planning and to propose erosion mitigation measures. In this context, we aim to determine the Soil Loss Tolerance limit to different soil classes located at the Coroado Stream Subbasin, southern Minas Gerais, Brazil. The soil classes of the subbasin area was classified as Dystrophic Red Latosols - LVd (90.0\%), Eutrophic Red-Yellow Argisols - PVAe (5.4\%), and Dystrophic Tb Haplic Cambisols - CXbd (1.9\%). The following attributes were used to determine the T limits: texture, depth, density, permeability, and organic matter. To analyzing these parameters, we collect soil samples at 18 points distributed along the subbasin area. T values

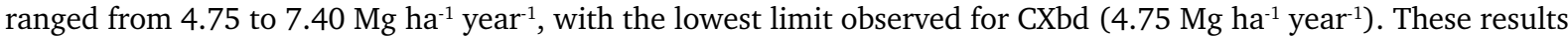
indicate that the Cambisol should be prioritized in the adoption of conservation practices to reduce water erosion and to maintain soil loss levels at acceptable rates. Latosols, Argisols, and Cambisols are the most common soils in the Brazilian territory. Thus, the results provided by the work can be used as a reference to monitoring the erosion process and evaluate the sustainability of agricultural activities in Brazil.
\end{abstract}

Keywords: Soil conservation. Water erosion. Agricultural sustainability.

\section{Avaliação do limite de tolerância à perda de solo para Latossolos, Argissolos e Cambissolos no sul de Minas Gerais}

\section{Resumo}

A Tolerância de perda de solo (TPS) é um parâmetro que reflete a taxa máxima de erosão que ainda permitirá um nível de produção sustentável das culturas agrícolas. As informações fornecidas pela TPS podem ser utilizadas como ferramenta para mitigar os impactos da erosão e como mecanismo para a proposição de práticas conservacionistas em bacias hidrográficas. Nesse cenário, o objetivo do trabalho foi determinar a Tolerância de Perda de Solo em diferentes classes de solos presentes na Sub-bacia Hidrográfica do Córrego Coroado, sul de Minas Gerais. Os solos da área foram classificados como Latossolos Vermelhos distróficos - LVd (90,0\%), Argissolos Vermelho-Amarelos eutróficos - PVAe

${ }^{1}$ Universidade Federal de Alfenas. Alfenas, MG. Brasil.

https://orcid.org/0000-0002-3560-9241

${ }^{2}$ Universidade Federal de Alfenas. Alfenas, MG. Brasil.

https://orcid.org/0000-0001-7443-9428

${ }^{3}$ Universidade Federal de Alfenas. Alfenas, MG. Brasil.

https://orcid.org/0000-0003-2621-7745

${ }^{4}$ Universidade Federal de Alfenas. Alfenas, MG. Brasil.

https://orcid.org/0000-0001-5961-0717

${ }^{5}$ Universidade Federal de Alfenas. Alfenas, MG. Brasil.

https://orcid.https://org/0000-0002-1001-4145

${ }^{6}$ Universidade Federal de Alfenas. Alfenas, MG. Brasil.

https://orcid.https://org/0000-0003-2484-9984

${ }^{7}$ Universidade Federal de Alfenas. Alfenas, MG. Brasil.

https://orcid.org/0000-0001-6077-5623

${ }^{8}$ Universidade Federal de Alfenas. Alfenas, MG. Brasil.

https://orcid.org/0000-0001-8127-0325

*Autor para correspondência: ronaldo.mincato@unifal-mg.edu.br

Recebido para publicação em 28 de outubro de 2019. Aceito para publicação em 08 de novembro de 2019

e-ISSN: 2447-6218 / ISSN: 2447-6218 / (C) 2009, Universidade Federal de Minas Gerais, Todos os direitos reservados. 
(5,4\%) e CambissolosHáplicos Tb distróficos - CXbd (1,9\%). Os limites de TPS foram determinados a partir da textura, profundidade, densidade, permeabilidade e teor de matéria orgânica dos solos. Para determinação destes parâmetros foram coletadas amostras de solo em 18 pontos distribuídos na sub-bacia. Os valores de TPS variaram entre 4,75 a 7,40 Mg ha-1 ano ${ }^{-1}$, com menor limite observado para o CXbd (4,75 $\left.\mathrm{Mg} \mathrm{ha}^{-1} \mathrm{ano}^{-1}\right)$. Dessa forma, o CXbd deve ser priorizado na adoção de práticas conservacionistas afim de reduzir a erosão hídrica e manter os níveis de perdas de solo em taxas aceitáveis. Latossolos, Argissolos e Cambissolos são os solos mais comuns no território brasileiro. Assim, os resultados encontrados no trabalho podem ser usados como referência para o monitoramento do processo erosivo e para promover a sustentabilidade agrícola.

Palavras-chave: Conservação do solo. Erosão hídrica. Sustentabilidade agrícola.

\section{Introduction}

After World War II, much of Europe was in ruins, and agricultural production systems were destroyed with various impacts on the soil. In this context, the Soil Loss Tolerance (T) concept arise, which was focusing mainly on the soil function in food production (Verheijen et al., 2009).

$\mathrm{T}$ reflects the maximum erosion rate that still allows a sustainable level of crop production (Wischmeier and Smith, 1978). The ideal $\mathrm{T}$ value is the erosion rate equivalent to the soil formation. However, due to the interactions between the pedogenetic factors, measure the soil formation rate is a complex task (Li et al., 2009). The $\mathrm{T}$ limit can be used to support the conservationist land-use planning and to propose erosion mitigation measures in agricultural activities (Nunes et al., 2012; Demarchi and Zimback, 2014).

The $\mathrm{T}$ determination in Brazilian soils is usual in large-scale studies (Oliveira et al., 2008; Bertol and Almeida, 2000). However, according to Duan et al. (2017), the $\mathrm{T}$ limits range widely, indicating that the use of a uniform pattern on regional-scale agricultural land is not accurate and does not reflect efforts to maintain the sustainability of agricultural systems. Thus, it is imperative to determine $\mathrm{T}$ values in a river basin scale to improve its application and reliability.
In this context, the objective of the study was to determine the T limits to different soil classes located at the Coroado Stream Subbasin, southern Minas Gerais, Brazil.

\section{Material and methods}

\section{Study area}

The research was carried out at the Capoeirinha farm (Ipanema Agrícola SA) located at Alfenas Municipality, southern of Minas Gerais state, Brazil, in the coordinates, UTM 405062 at $406420 \mathrm{~m} \mathrm{E}$ and 7618526 at $7618610 \mathrm{~m} \mathrm{~N}$, zone 23K, Datum SIRGAS 2000) (Figure 1). The area has 1285.2 ha located in the Córrego Coroa do sub basin, which belongs to the Rio Grande hydrographic basin. According to Köppen, the climate was classified as Mesothermal Tropical (Cwb), with an average annual temperature of $22{ }^{\circ} \mathrm{C}$ and an average annual rainfall of $1500 \mathrm{~mm}$ (Alvares et al., 2013). Altitudes range from 793 to $942 \mathrm{~m}$ with an average of $868 \mathrm{~m}$.

The subbasin relief is present in the Declivity Map (Figure 2), which was elaborated by the ArcMap 10.3 Slope tool (ESRI, 2015) (Figure 1), from the Digital Elevation Model extracted from the contour lines of the Minas Gerais state map (SISEMA, 2019). The area presents an average slope of $12.7 \%$ and a predominantly rolling relief $(8-20 \%)$.

Figure 1 - Location and slope map of the Coroado Stream subbasin, located at Alfenas, southern Minas Gerais, Brazil
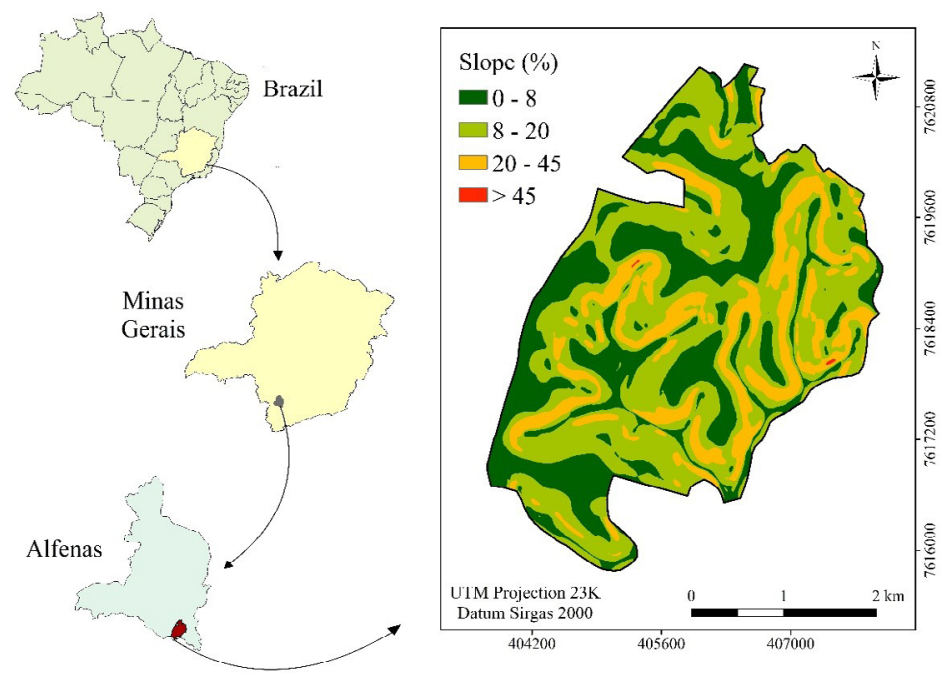

Cad. Ciênc. Agrá., v. 11, p. 01-06, 2019. e-ISSN: 2447-6218 / ISSN: 1984-6738 
Coffee is the main subbasin land-use class and occupies $46.3 \%$ of the area. The cultivation of coffee in steep slopes is traditional in the region and characterized the mountain coffee. The area also presents the following land use and occupation classes: maize (10.4\%), eucalyptus (5.3\%), native and regenerating forests (29.0\%), access roads $(5.1 \%)$, facilities $(1.1 \%)$ and drainage $(2.8 \%)$.

The land use map (Figure 2A) was elaborated based on field surveys and images from the Landsat- 8
Operational Land Imager (OLI) satellite, bands 2, 3 and 4 , in orbit 219 , point 75 , obtained from the Division of Imaging (INPE, 2019) and process at ArcMap 10.3 software (ESRI, 2015). The soil classes of the study area are Dystrophic Red Latosols - LVd (90.0\%), Eutrophic Red-Yellow Argisols - PVAe (5.4\%), and Dystrophic Tb Haplic Cambisols - CXbd (1.9\%). The digital soil map (Figure 2B) was prepared using the Minas Gerais State Soil Map (UFV et al., 2010) combined with morphological field descriptions.

Figure 2 - Land use and occupation map (A) and Digital soil map with sampling points (B) of the Coroado Stream subbasin, located at Alfenas, southern Minas Gerais, Brazil. Notes: LVd = Dystrophic red Latosol, PVAe = Eutrophic red-yellow Argisol, CXbd = Haplic Tb dystrophic Cambisol, RO = Rocky Outcrop

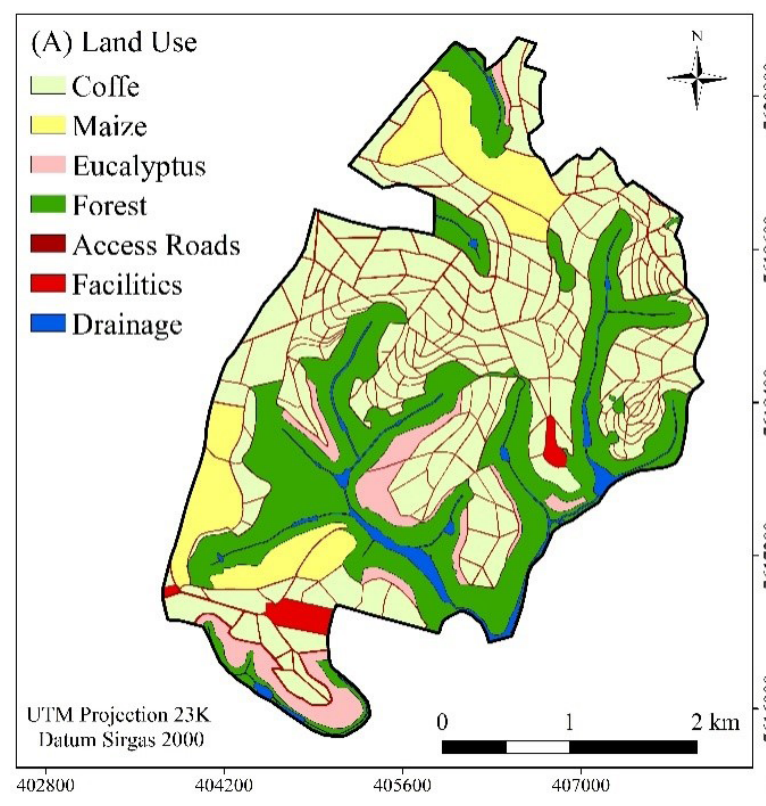

\section{Soil Loss Tolerance(T)}

The soil loss tolerance was calculated according to the Equation 1 proposed by Bertol and Almeida (2000):

$$
\mathrm{T}=100 \cdot \mathrm{h} \cdot \mathrm{r}_{\mathrm{a}} \cdot \mathrm{m} \cdot \mathrm{p} \cdot \mathrm{Ds} \cdot 1000^{-1} \text { (Eq. 1) }
$$

Where: $\mathrm{T}$ is the soil loss tolerance $\left(\mathrm{Mg} \mathrm{ha}^{-1}\right.$ year$\left.{ }^{1}\right)$; $h$ is the effective soil depth $(\mathrm{cm})$, limited to $100 \mathrm{~cm}$; $r_{a}$ is the ratio that expresses, mutually, the effect of the textural relationship between the horizons $\mathrm{B}$ and $\mathrm{A}$ and the clay content of the horizon $\mathrm{A} ; \mathrm{m}$ is the factor that expresses the organic matter content in the $0-20 \mathrm{~cm}$ soil depth; $\mathrm{p}$ is the soil permeability factor; Ds is the soil density $\left(\mathrm{kg} \mathrm{dm}^{-3}\right)$ e 1.000 is the constant that represents the time period required to wear a soil layer of $1000 \mathrm{~mm}$ depth.

Disturb and Undisturbed soil samples were collected at 18 points in the surface $(0-20 \mathrm{~cm})$ and subsurface $(20-60 \mathrm{~cm})$ layers, using a probe and a cylindrical sam-

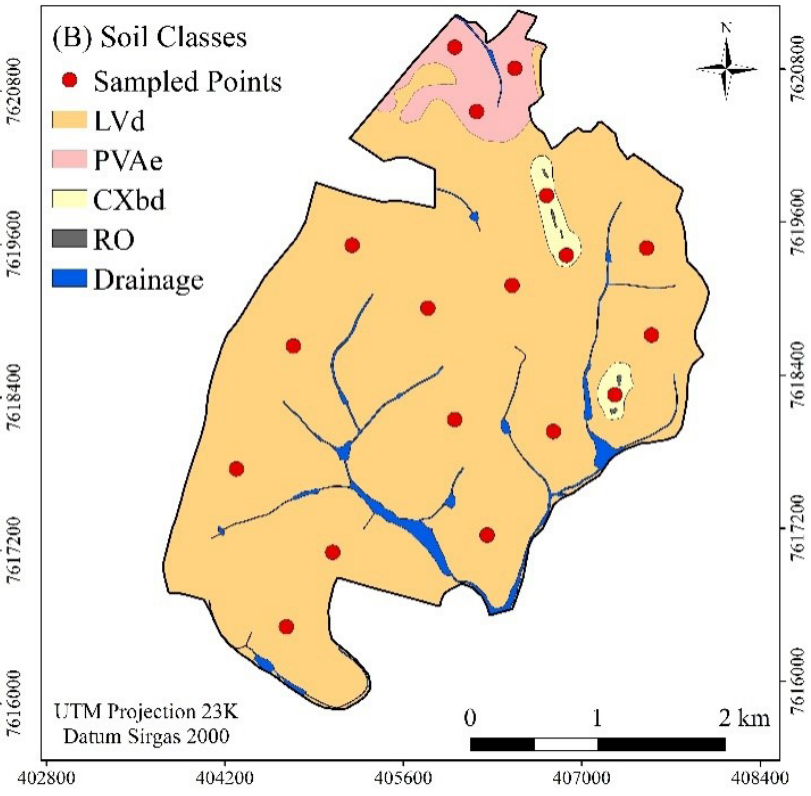

pler $\left(92.53 \mathrm{~cm}^{3}\right)$, respectively (Figure 2A). Soil depth and morphological description were determined in $40 \mathrm{x} 40 \mathrm{x}$ $60 \mathrm{~cm}$ micro trenches, according to Santos et al. (2005). Soil organic matter content was determined according to Embrapa (2017), while the particle size distribution by the pipette method with $0.1 \mathrm{~mol} \mathrm{~L}^{-1} \mathrm{NaOH}$ (Gee and Bauder, 1986) and the soil density using the undisturbed samples (Blake and Hartge, 1986).

The ra parameter is obtained by the relation of clay content between the surface $(0-20 \mathrm{~cm})$ and subsurface $\left(20-60 \mathrm{~cm}\right.$ ) layers. For textural ratios below 1.5, $\mathrm{r}_{\mathrm{a}}$ values of $1.0,0.9$, and 0.8 were assigned for soils with $\mathrm{A}$ horizon clay content higher than $40 \%$, between 40 and $20 \%$, and less than $20 \%$, respectively. The m parameter was also weighted at $1.00,0.85$, and 0.70 for soil organic matter content higher than 5.0 , between 5.0 and 2.5 , and less than $2.5 \mathrm{dag} \mathrm{kg}^{-1}$, respectively (Bertol and Almeida, 2000). The soil permeability was classified according to Table 1. 
Lense, G. H. E. et al.

Table 1 - Soil permeability classes as a function of soil texture and structure degree, according to Galindo and Margolis (1989)

\begin{tabular}{cccc}
\hline Texture & Structure degree & $\begin{array}{c}\text { Permeability } \\
\text { classes }\end{array}$ & $\begin{array}{c}\text { Weighting value for the } \mathbf{~} \\
\text { calculation* }\end{array}$ \\
\hline $\begin{array}{c}\text { Clay and very clay } \\
(\text { Clay }>35 \%)\end{array}$ & Weak & Weak & 0.70 \\
& Moderate & Weak & 0.70 \\
Strong & Moderate & 0.85 \\
\hline Medium & Weak & Moderate & 0.85 \\
& Moderate & Moderate & 0.85 \\
\hline Sandy $<35 \%)$ & Strong & Fast & 1.00 \\
\hline Clay + silt $<15 \%)$ & Weak & Moderate & 0.85 \\
& Moderate & Fast & 1.00 \\
& Strong & Fast & 1.00
\end{tabular}

Adapted from Galindo and Margolis (1989) and Oliveira et al. (2008). Notes: T = Soil Loss Tolerance, *weighting value adapted from de Bertol e Almeida (2000).

\section{Results and discussion}

The structure of the LVd was classified as granular with moderate degree and medium size, while the PVAe and CXbd classes were classified as angular blocks with respective moderate and weak degrees, and medium size. According to the texture, the soil was classified, as clay (LVd and PVAe) and sandy clay loam (CXbd). PVAe showed a higher textural relationship and soil organic matter content (Table 2).

Table 2 - Variables analyzed for the different soil classes of the Coroado Stream Subbasin, located at Alfenas, southern Minas Gerais, Brazil

\begin{tabular}{ccccc}
\hline Soil & $\begin{array}{c}\text { Clay content of } \\
\text { Horizon A (\%) }\end{array}$ & $\begin{array}{c}\text { Textural relation } \\
\left(\mathrm{g} \mathrm{kg}^{-1}\right)\end{array}$ & $\begin{array}{c}\text { Organic matter content } \\
\left(\mathrm{kg} \mathrm{dm}^{-3}\right)\end{array}$ & $\begin{array}{c}\text { Average depth } \\
(\mathrm{m})\end{array}$ \\
\hline LVd & 54 & 0.95 & 2.56 & 2.70 \\
PVAe & 56 & 1.07 & 2.75 & 2.55 \\
CXbd & 29 & 1.02 & 2.45 & 0.71 \\
\hline
\end{tabular}

Notes: LVd $=$ Dystrophic red Latosol, PVAe $=$ Eutrophic red-yellow Argisol, CXbd $=$ Haplic Tb dystrophic Cambisol.

The permeability of CXbd was classified as moderate, while the high clay content provided to the PVAe and LVd classes a slow permeability. The soil depth ranged from 0.71 to $2.70 \mathrm{~m}$ (Table 2), and the average density ranged from 1.21 to $1.25 \mathrm{~kg} \mathrm{dm}-3$ (Table 3). The values of the parameters used in the $\mathrm{T}$ calculations are present in Table 3.

Table 3 - Variables used in the calculation of the Soil Loss Tolerance (T) limit in the Coroado Stream Hydrographic Subbasin, Alfenas, south of Minas Gerais, Brazil

\begin{tabular}{ccccccc}
\hline \multirow{2}{*}{ Soil } & $\mathbf{h}$ & $\mathbf{r}_{\mathbf{a}}$ & $\mathbf{m}$ & $\mathbf{p}$ & $\mathbf{D s}$ & $\mathbf{T}$ \\
\cline { 2 - 7 } & $\mathrm{cm}$ & dimen. & dimen. & dimen. & $\mathrm{kg} \mathrm{dm}^{-3}$ & $\mathrm{Mg} \mathrm{ha-1}^{-1} \mathrm{year}^{-1}$ \\
\hline LVd & 100 & 1.0 & 0.85 & 0.7 & 1.24 & 7.40 \\
PVAe & 100 & 1.0 & 0.85 & 0.7 & 1.21 & 7.20 \\
CXbd & 71 & 0.9 & 0.7 & 0.85 & 1.25 & 4.75
\end{tabular}

Notes: $\mathrm{h}=$ effective soil depth; $\mathrm{r}_{\mathrm{a}}=$ relationship that expresses, together, the effect of the textural relation between the horizons $\mathrm{B}$ and A and the clay content of the A horizon; $\mathrm{m}=$ factor that expresses the organic matter content in the $0-20 \mathrm{~cm}$ soil depth; $\mathrm{p}=$ soil permeability factor; Ds = soil density; $\mathrm{T}=$ soil loss tolerance; dimen = dimensionless; LVd = Dystrophic red Latosol, PVAe = Eutrophic red-yellow Argisol, CXbd = Haplic $\mathrm{Tb}$ dystrophic Cambisol. 
Assessment of Soil loss Tolerance limit to Latosol, Argisol and Cambisolin the southern Minas Gerais state

We found $\mathrm{T}$ values lower than $11.20 \mathrm{Mg} \mathrm{ha}^{-1}$ year ${ }^{1}$, which is the limit determined by Wishmeier and Smith (1978). The results obtained for the LVd are below the limit established by Lombardi Neto and Bertoni (1975) that range from 9.60 to $15.00 \mathrm{Mg} \mathrm{ha}^{-1}$. According to Duan et al. (2017), this result is due to the wide variation of $\mathrm{T}$ values among the same soil classes. For PVAe, the $\mathrm{T}$ limits are close to the results found by Oliveira et al. (2008), who observed an average of 7.03 $\mathrm{Mg} \mathrm{ha}^{-1}$ year $^{-1}$ in Argisols of Paraíba state.

Density was the main factor that influences the difference found between the T values of LVd and PVAe (Table 3). Soil attributes are weighted before the T calculation, which may lead some factors to have their effect masked or intensified in the index result. Although the $\mathrm{T}$ has an empirical character, the index results cannot faithfully indicate a tolerable soil loss. However, $\mathrm{T}$ is a useful tool to support the conservationist land use planning (Bertol and Almeida, 2000).

Due to the low T limits observed for CXbd (4.75 $\mathrm{Mg}$ ha-1 year $^{-1}$ ), this soil class should be prioritized in the adoption of conservation practices to reduce water erosion and maintain soil loss levels at acceptable rates. Therefore, this soil should be used mainly to native vegetation protection and to support grasslands cultivation.

It is worth mentioning that $\mathrm{T}$ values do not impose arbitrary restrictions on soil management, only act as a guide to landowners make choices of management techniques (Lombardi Neto and Bertoni, 1975). Moreover, considering soils with slow formation rates, any losses above $1 \mathrm{Mg}^{-1}$ year $^{-1}$ can cause irreversible damage to its long-term quality (Stefano and Ferro, 2016). Thus, in the short term, $\mathrm{T}$ can be used as a sustainability index, but even in situations with low erosion rates, practices that seek to reduce soil losses to values close to zero should be adopted to ensure soil production capacity and agricultural system sustainability.

\section{Conclusion}

We calculated the Soil Loss Tolerance limits to Latosols, Argisols, and Cambisols in the Coroado Stream subbasin. The limits found in the subbasin area ranged from 4.75 to $7.40 \mathrm{Mg}^{-1}$ year $^{-1}$, and the Latosol presents the highest values, followed by the Argisol and Cambisol. Since these are the most common soils found in the Brazilian territory, the results provided by the work can be used as a reference to monitoring the erosion process and promote the sustainability of agricultural activities.

\section{Acknowledgment}

The authors thank the Fundação de Amparo à Pesquisa do Estado de Minas Gerais (FAPEMIG) for the scholarship offered to the first author. To Ipanema Agrícola S. A. for funding the research and conceding the study area. This study was financed in part by the Coordenação de Aperfeiçoamento de Pessoal de Nível Superior - Brasil (CAPES) - Finance Code 001.

\section{References}

Alvares, C. A.; Stape, J. L.; Sentelhas, P. C.; Gonçalves, J. L. M.; Sparovek, G. 2013. Köppen's climate classification map for Brazil. Meteorologische Zeitschrift, 22: 711-728. Doi: https://doi.org/10.1127/09412948/2013/0507.

Bertol, I.; Almeida, J. A. 2000. Tolerância de perda de solo por erosão para os principais solos do estado de Santa Catarina. Revista Brasileira de Ciência do Solo, 24: 657-668. Doi: http://dx.doi.org/10.1590/ S0100-06832000000300018.

Blake, G. R.; Hartge, K. H. 1986. Bulk density. p. 363-375. In: KLUTE, A. Methods of soil analysis. 2. ed. Madison: American Society of Agronomy.

Demarchi, J. C.; Zimback, C. R. L. 2014. Mapeamento, erodibilidade e tolerância de perda de solo na sub-bacia do Ribeirão das Perobas. Energia na Agricultura, 29: 102-114. Doi: https://doi.org/10.17224/ EnergAgric.2014v29n2p102-114.

Duan, X.; Shi, X.; Li, Y.; Rong, L.; Fen, D. 2017. A new method to calculate soil loss tolerance for sustainable soil productivity in farmland. Agronomy for Sustainable Development, 37: 2-13. Doi: https://doi. org/10.1007/s13593-016-0409-3.

Empresa Brasileira de Pesquisa Agropecuária - Embrapa. 2017. Manual de métodos de análise do solo. 3. ed. rev. Brasília, DF: Embrapa. Disponível em :https://www.infoteca.cnptia.embrapa.br/bitstream/ doc/990374/1/ManualdeMtodosdeAnilisedeSolo.pdf
Environmental Systems Research Institute - ESRI. 2015. ARCGIS Professional GIS for the desktop version 10.3. Redlands, Califórnia, EUA, Software.

Galindo, I. C.; Margolis, E. 1989. Tolerância de perdas por erosão para solos do Estado de Pernambuco. Revista Brasileira de Ciência do Solo, 13: 95- 100.

Gee, G. W.; Bauder, J. W. 1986. Particle-size analysis. p. 383-411. In: KLUTE, A. Methods of soil analysis: physical and mineralogical methods. 2. ed. Madison: American Society of Agronomy.

Infraestrutura de Dados Espaciais do Sistema Estadual de Meio Ambiente e Recursos Hídricos - SISEMA. 2019. Plataforma digital de dados espaciais. Belo Horizonte: IDE-Sisema, 2019. Available in: http:// idesisema.meioambiente.mg.gov.br/.

Instituto Nacional de Pesquisas Espaciais - INPE. 2019. SGI 2.5 Divisão de Geração de Imagens (DIDGI). SGI. Imagem Geosistemas, São José dos Campos: Instituto Nacional de Pesquisas Espaciais. Available in: http://www.dgi.inpe.br/CDSR/.

Li, L.; Du, S.; Wu, L.; Liu, G. 2009. An overview of soil loss tolerance. Catena, 78: 93-99. Doi: https://doi.org/10.1016/j.catena.2009.03.007.

Lombardi Neto, F; Bertoni, J. 1975. Tolerância de perdas de terra para solo do Estado de São Paulo. Campinas, Instituto Agronômico de Campinas. 
Lense, G. H. E. et al.

Nunes, J. G.; Campos, M. C. C; Oliveira, F. P; Nunes, J. C. 2012. Tolerância de perda de solo por erosão na região sul do Amazonas. Ambiência - Revista do Setor de Ciências Agrárias e Ambientais, 8: 859-868. Doi: https://doi.org/10.5777/ambiencia.2012.05.05.

Oliveira, F. P.; Santos, D.; Silva, I. F.; Silva, M. L. N. Tolerância de perda de solo para o Estado da Paraíba. Revista de Biologia e Ciência da Terra, 8: 60-71, 2008. Available in: http://www.dcs.ufla.br/site/_adm/ upload/file/pdf/Prof\%20Marx/Aula\%204/Art\%20estudo/Oliveira\%20 et\%20al_\%202008.pdf.

Santos, R. D.; Lemos, R. C.; Santos, H. G.; Ker, J. C.; Anjos, L. H. C. 2005. Manual de descrição e coleta de solos no campo. 5. ed. Viçosa: Sociedade Brasileira de Ciência do Solo - SBCS, Empresa Brasileira de Pesquisa Agropecuária - Embrapa, Centro Nacional de Pesquisa de Solos - Cnps.
Stefano, C. D.; Ferro, V. 2016. Establishing soil loss tolerance: an overview. Journal of Agricultural Engineering, Paiva, 47: 127-133, 2016. Doi: https://doi.org/10.4081/jae.2016.560.

UFV - CETEC - UFLA - FEAM, 2010. Mapa de solos do Estado de Minas Gerais. Belo Horizonte, Fundação Estadual do Meio Ambiente. Available in: http://www.feam.br/noticias/1/949-mapas-de-solo-doestado-de-minas-gerais.

Verheijen, G. G. A.; Jones, R. J. A.; Rickson, R. J., Smith, C. J. 2009. Tolerable versus actual soil erosion rates in Europe. Earth-Science Reviews, 94: 23-38. Doi: https://doi.org/10.1016/j.earscirev.2009.02.003.

Wischmeier, W. H.; Smith, D. D. 1978. Predicting rainfall erosion losses. A guide to conservation planning. Supersedes Agriculture Handbook. Washington, United States Department of Agriculture. Diponível em: https://www.ars.usda.gov/ARSUserFiles/64080530/RUSLE/AH_703. pdf 